REPORTS OF MORPHOLOGY
$\begin{gathered}\text { Official Journal of the Scientific Society of Anatomists, } \\ \text { Histologists, Embryologists and Topographic Anatomists } \\ \text { of Ukraine } \\ \text { journal homepage: https://morphology-journal.com }\end{gathered}$

\title{
Determination of individual linear and angular characteristics of the position of upper central incisors in Ukrainian young men and women with orthognathic bite
}

Dmitriev M.O., Gunas I.V., Gnenna V.O., Smolko N.M.

National Pirogov Memorial Medical University, Vinnytsya, Ukraine

\section{ARTICLE INFO}

Received: 28 September, 2018

Accepted: 17 October, 2018

UDC: $616.716 .8-071-084: 613.956$ :

617.52: $616.34 .25-007.481-7$

\section{CORRESPONDING AUTHOR}

e-mail: dmitriyevnik@gmail.com Dmitriev M.O.

\begin{abstract}
Taking into account the importance of determining the teleroentgenographic indicators of the spatial position of central incisors, arises a scientific and clinical interest in conducting such studies. The purpose of the study is to develop mathematical models of individual characteristics of the position of upper central incisors in young men and women of Ukraine with orthognathic bite by studying the cephalometric indices and conducting direct stepwise regression analysis. With the help of Veraviewepocs $3 D$ device, Morita (Japan) 38 young men (aged 17 to 21 years) and 55 young women (aged 16 to 20 years) with occlusion close to orthognathic bite and balanced faces received side teleroentgenograms. Cephalometric analysis was performed using OnyxCeph ${ }^{3 \mathrm{TM}}$ software. Cephalometric points and measurements were performed according to the recommendations of A.M. Schwarz, J. McNamara, W.B. Downs, R.A. Holdway, P.F. Schmuth, C.C. Steiner and C.H. Tweed. In the licensed statistical package "Statistica 6.0", using the direct stepwise regression analysis, the following teleroentgenographic characteristics of the position of the upper central incisors were performed: distance 1u_APog, distance 1u_Avert, distance 1u_NA, angle Max1_NA, angle Max1_SN and angle Max1_SpP. In young men and women with occlusion close to orthognathic bite and balanced face, reliable regression models of individual teleroentgenographic characteristics of the position of upper central incisors with a determination coefficient of greater than 0.50 have been developed, depending on the peculiarities of the metric characteristics of the craniofacial complex: in young men of 6 possible models, have been constructed 5 with coefficients of determination $R^{2}$ from 0.672 to 0.928 , and for young women - all 6 possible models with determination coefficient $R^{2}$ from 0.508 to 0.663 . In the analysis of models with a determination coefficient higher than 0.50 , it was found that in young men most often the regression equations include - the angle AB_NPOG (12.0\%); distance COND_GN, inclination angle I, MAX maxillary length, Se_N distance, Nap angle, NBa-PtGn angle, SND angle and Wits indicator (by 8.0\%). In young women most often models include - the angle $A B$ NPOG and the Wits indicator (by 15.4\%); angle N_POG (11.5\%); the angle GI'SnPog' and the distance LPALAT (by 7.7\%).

Keywords: upper central incisors position, cephalometry, regression analysis, young men and women, orthognathic bite.
\end{abstract}

\section{Introduction}

One of the most common reasons for appeals to an orthodontist doctor is to improve your smile and not only change the color of the teeth but also position of the frontal group of teeth. After all, in a society successful, prospective, position in society is often associated with beauty and a beautiful smile [36].

The rapid development of computed technology and the use of digital tools offers a new perspective for daily clinical activity. They allow the physician to visualize the ultimate goal of treatment, taking into account the basic laws of aesthetics and harmony, as well as the patient's own wishes, creating an effective communication tool between the dentist and the patient.

When assessing the smile and facial expression in a

(C) 2018 National Pirogov Memorial Medical University, Vinnytsya 
non-stressed condition, which is usually evaluated in three projections [30], the physician pays attention to the shape, size and position of the front teeth. The use of digital smile design tools - DSD (digital smile design) [16, 25, 29, 31, 38] helps to determine if there is a need to change the shape and size of the teeth themselves by direct or indirect restorations. But if you need to change your face profile, you often need orthodontic treatment. After all, orthodontists, having the ability to change the position of the frontal group of teeth, can also significantly affect the patient's profile. Many studies are devoted to this issue and changes that occur with the face during and after orthodontic treatment are described and continue to be studied by many authors [4, $15,23,37,45,46]$.

But the doctor who plans to change the person's face needs to have a clear idea not only about the average standard values of the corresponding facial and dental indices, but also to take into account the ethnic peculiarities of the perception of the true meaning of "beauty" [42], face type [32], and also taking into account aesthetic preference of the patient when creating an individual treatment plan $[5,7]$.

Taking into account the importance of determining the teleroentgenographic indices of the spatial position of central incisors and the diversity of the proposed methods [14, 28, $40,43]$, as well as the lack of the possibility of identifying the individual normal values of these indicators, there is a scientific and clinical interest in conducting research on these issues. And the use of modern mathematical techniques allows us to develop tools for determining the individual normal values of the position of central incisors, taking into account their ethnic [24, 27], sexual, age [26] and anatomical [6] features of man.

The purpose of the study is to develop mathematical models of individual characteristics of the position of upper central incisors in young men and women of Ukraine with orthognathic bite by studying the cephalometric indices and conducting direct stepwise regression analysis.

\section{Materials and methods}

With the help of Veraviewepocs 3D device, Morita (Japan) in 38 young men ( 17 to 21 years of age) and 55 young women (aged 16 to 20 years) with occlusion close to the orthognathic bite and balanced face received side teleroentgenograms. Cephalometric analysis was performed using OnyxCeph ${ }^{3 \mathrm{TM}}$ software. Cephalometric points and measurements were performed according to the recommendations of A.M. Schwarz, J. McNamara, W.B. Downs, R.A. Holdway, P.F. Schmuth, C.C. Steiner and C.H. Tweed [14, 20, 21, 28, 33, $40,41,43]$. The analysis of teleroentgenograms and the results of their researches for Ukrainian young men and women is described in detail and set out in a number of articles [8-11, 18, 19, 44].

We, in accordance with the above-mentioned methods, simulated the following teleroentgenographic characteristics of the position of the upper central incisors (Fig. 1): APOG_1U (distance 1u_APog) - the distance from the point Is1u (the

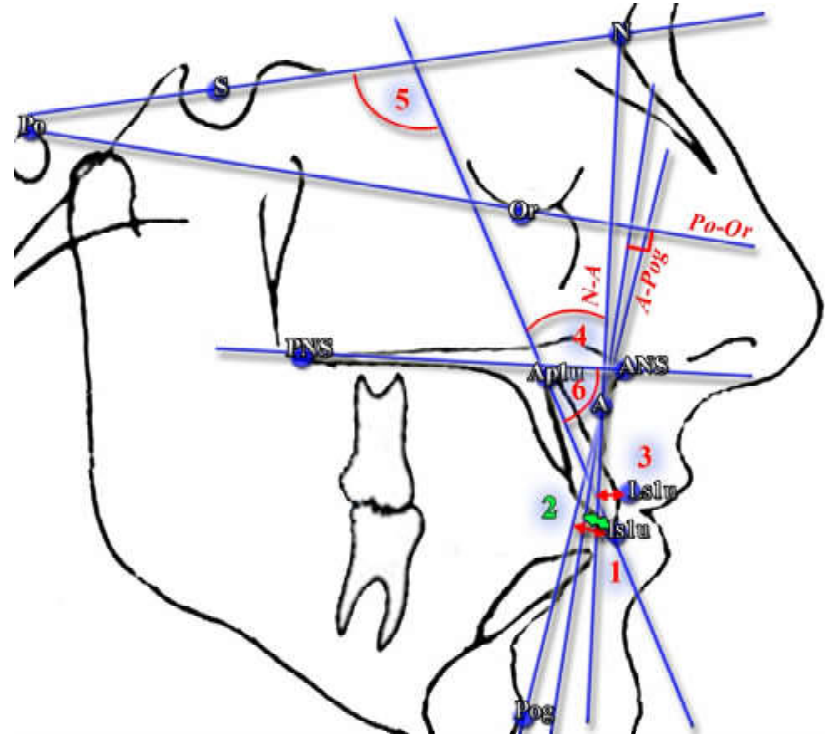

Fig. 1. Teleroentgenographic linear and angular characteristics of the position of upper central incisors. 1-APOG_1U (distance 1u_APog ); 2 -AVERT_1U (distance 1u_Avert); 3-NA_1U (distance 1u_NA); 4 - MAX1_NA (angle Max1_NA); 5 - MAX1_SN (angle Max1_SN); $6-$ MAX1_SPP (angle Maxi_SpP).

incisal edge of the upper central incisor) to the line A-Pog; AVERT_1U (distance 1u_Avert) is the distance from the point of Is $1 \mathrm{u}$ (the incisal edge of the upper central incisor) to the perpendicular to the Frankfurt plane ( $\mathrm{Po}-\mathrm{Or})$ through the point $A$ (if the distance located medially, that is, the incisal edge of the incisor is in the front with respect to the line position, then the indicator takes a positive value, and if the distance is distal, that is, the incisal edge of the incisor is in the posterior with respect to the line position, then the figure takes a negative value); NA_1U (distance 1u_NA) - distance from the point $\mathrm{Ls} 1 \mathrm{u}$ to the line $\underline{\mathrm{N}-\mathrm{A}}$ (defines the anteriorposterior arrangement of the crown part of the upper central incisor to the line $\underline{N-A}$ ); MAX1_NA (angle Max1_NA) - is formed by the lines Ap1u-Is1u (inclination of the central axis of the upper central incisor) and N-A; MAX1_SN (angle Max1_SN) - formed by the lines Ap1u-Is1u (inclination of the central axis of the upper central incisor) and S-N; MAX1_SPP (angle Max1_SpP) - is formed by lines Ap1u-Is1u (inclination of the central axis of the upper central incisor) and ANS-PNS (palatal plane $\underline{S p P}$ ).

Construction of models of linear and angular characteristics of the position of upper central incisors, depending on the peculiarities of the metric parameters of the skull, is carried out in the statistical package "Statistica 6.0 " using straight-line regression analysis.

\section{Results}

As a result of modeling teleroentgenographic characteristics of the position of upper central incisors in young men and women with occlusion close to orthognathic bite and balanced faces, depending on the metric parameters of the skull, we have constructed linear equations for the 
following indices.

For young men:

AVERT_1U $=-22.96+0.271 \times$ AB_NPOG $+0.222 \times I+$ $0.278 \times$ PN_A + 0.177 $\times$ NBA_PTGN $-0.317 \times$ MAX + $0.073 \times$ COND_GN $\left(R^{2}=0.748 ; F_{(6.30)}=14.85 ; p<0.001\right.$; Error of estimate $=1.077$ ),

NA_1U $=-18.55+0.265 \times A B \_N P O G+0.137 \times$ LPALAT + $0.166 \times$ N_SE $-0.369 \times \mathrm{MAX}+0.149 \times \mathrm{I}+0.117 \times$ NBA_PTGN $\left(R^{2}=0.729 ; F_{(6.30)}=13.48 ; p<0.001\right.$; Error of estimate $\left.=0.943\right)$,

MAX1_NA $=14.28-0.774 \times$ NAPOG $+0.172 \times$ S_L $\left(R^{2}=0.672 ; F_{(2.33)}=33.73 ; p<0.001\right.$; Error of estimate=3.241),

MAX1_SN $=-73.09+1.863 \times$ SND $+1.992 \times A B \_N P O G+$ $1.611 \times$ WITS $+0.502 \times$ NAPOG $+0.224 \times$ NSBA $+0.209 \times$ N_SE $\left(R^{2}=0.929 ; F_{(6.29)}=62.98 ; p<0.001\right.$; Error of estimate $=2.218$ ),

MAX1_SPP $=164.0+0.550 \times$ SND $-1.165 \times \mathrm{MM}+1.411$ $x$ WITS + $0.113 \times$ COND_GN + $0.184 \times$ ML_NSL $\left(R^{2}=0.819\right.$; $F_{(5.30)}=27.24 ; p<0.001$; Error of estimate $\left.=2.612\right)$.

The regression model of the distance of $1 \mathrm{u}$ _APog in young men with orthognathic bite has a determination coefficient of less than $0.5(R 2=0.483)$ and therefore has no practical significance for orthodontists.

For young women:

APOG_1U $=-2.900+0.376 \times$ N_POG_ $+0.128 \times$ AFH $0.152 \times \bar{G} L_{-} S N P O G-0.028 \times \bar{G} L_{-} S \bar{N}_{-} S\left(R^{2}=0.508\right.$; $F_{(4.49)}=12.66 ; p<0.001 ;$ Error of estimate $\left.=1.323\right)$,

AVERT_1U $=-30.08+0.264 \times$ P_OR_N $+0.342 x$ $A B \_N P O G+0.283 \times$ N_POG_+ $0.085 \times$ COND_GN -0.092 $x \overline{G L}$ _SNPOG $\left(R^{2}=0.663 ; F_{(5.48)}^{-}=18.87 ; p<0.001\right.$; Error of estimate=1.244),

NA_1U $=0.248+0.505 \times A B \_N P O G+0.165 \times N$ NOG_+ $0.198 \times$ MAX_MAND + $0.212 \times$ WITS $\left(R^{2}=0.662 ; F_{(4.49)}=24.01\right.$; $\mathrm{p}<0.001$; Error of estimate $=1.056)$,

MAX1_NA $=36.62+1.258 \times$ AB_NPOG $-1.301 \times$ SN_GOGN $+1.017 \times \mathrm{ML}$ NSL $+0.591 \times$ WITS $\left(R^{2}=0.561\right.$; $F_{(4.46)}=14.67 ; p<0.001$; Error of estimate=3.710),

MAX1_SN $=-36.70+1.806 \times S N D+0.832 \times A B \_N P O G+$ $1.010 \times$ WITS + $0.423 \times$ LPALAT $-0.297 \times$ S_L $\left(\bar{R}^{2}=0.649\right.$; $F_{(5.45)}=16.65 ; p<0.001$; Error of estimate $\left.=3.55 \overline{3}\right)$,

MAX1_SPP $=210,9-1,211 \times \mathrm{MM}+0,628 \times \mathrm{ANB}+0,698 \mathrm{x}$ WITS + 0,349 x LPALAT $\left(R^{2}=0,575 ; F_{(4,46)}=15,54 ; p<0,001\right.$; Error of estimate $=3,817$ ).

In these models: $R^{2}$ - coefficient of determination; $F_{(!, ! !)}=! !, ! !$ - critical $($,!!!) and got (!!,!!!) value of Fisher's criterion; St. Error of estimate - standard error of the standardized regression coefficient; $A B$ NPOG - angle formed by lines $\underline{A-B}$ and $\underline{N}$ -

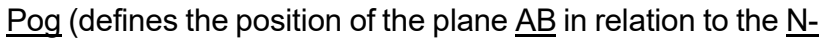
pog); AFH (distance AFH or front height of the face) - distance from the point Me to the line ANS-PNS; ANB (angle ANB) - is formed by lines $\underline{A}-\mathrm{N}$ and $\underline{\mathrm{N}-\mathrm{B}}$ (indicates an angular interstitial relation in the anterior-posterior direction; angle ANB is considered positive if point $\underline{A}$ is in front of $\underline{N B}$; if the lines $\underline{N A}$ and $\underline{N B}$ overlap, then the $A \overline{N B}$ angle is $0^{\circ}$; if point $\underline{A}$ is behind the $\underline{N B}$ line, then the angle is considered negative); COND_GN (effective length of mandible, or distance COND_GN) - distance from the point Cond to the point $\underline{\mathrm{Gn}}$; GL_SN_S (index Gl'Sn_Sn_Gn' or facial vertical index) -

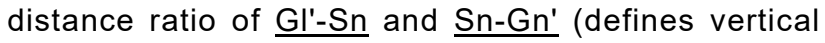
relationships in the face profile); GL_SNPOG (angle Gl'SnPog' or indicator of convexity of the soft tissue profile) formed by lines Gl'-Sn and Sn-Pog'; I (angle I, inclination angle) - angle formed by line ANS-PNS and Pn (nasal perpendicular, perpendicular to the line from the point $\underline{\mathrm{N}}$ to the line Se-N), angle of inclination of the upper jaw (spinal plane) to the nasal perpendicular; LPALAT (the value of the base of the upper jaw, CT-indicator) - distance between points $\underline{\text { ANS }}$ and PNS; MAX (length of the upper jaw) - distance from the constructive point apMax to the point PNS; MAX_MAND (maxillo-mandibular difference) - difference between distances Cond-A and Cond-Gn; ML_NSL (angle ML_NSL, or angle SN_GoMe) - is formed by lines tGo-Me and $\underline{\mathrm{S}-\mathrm{N}}$ (angle of inclination of the mandibular plane to the base of the skull); MM (maxillo-mandibular angle) - is formed by lines $\underline{A-B}$ and ANS-PNS (defines the angle below which the upper jaw is located in relation to the lower jaw in the jet plane); N_POG_ (angle N'Hold_Pog'_Hline) - angle between lines $\underline{\text { Ls-Pog' }}$ ( $\mathrm{H}$ line, Holdway line) and N'Hold-Pog'; N_SE (distance $\mathrm{Se} \_\mathrm{N}$ or the length of the front of the skull base by Steiner) - distance from the point Se to the point $\underline{\text { N }}$ NAPOG (angle of the skeletal face obliquity, or angle NaPog) - formed by lines $\mathrm{N}$-A and A-Pog; NBA_PTGN (angle NBa-PtGn or the angle of the front axle) - formed by lines $\mathrm{N}-\mathrm{Ba}$ and $\mathrm{Pt}-\mathrm{Gn}$ (determines the direction of development of the mandible); NSBA (angle NSBA) - formed by lines S-N (the front part of the skull base) and S-Ba; $P$ OR_N (soft tissue angle, or angle P_Or_N'Hold_Pog') - formed by lines $\mathrm{Po-Or}$ and N'Hold-Pog'; PN_A (distance PN_A) - distance from the point $\underline{A}$ to the point $\mathrm{PNm}$ (perpendicular line from the point $\underline{N}$ to the line $\underline{P_{0}-O r}$ ). If the point $\underline{A}$ is distal from the nasal perpendicular, then the indicator takes a negative value, and if the medial than a positive value; S_L (distance S_L or the front length of the skull base by Steiner) - from the point $\underline{S}$ to a constructive point $\underline{L}$, which is formed at the intersection of the perpendicular carried out from the point Pog to the line Se-N; SN_GOGN (angle SN_GoGn) - is formed by lines Go-Gn and S-N (angle of inclination (MpSt) mandibular plane by Steiner, to the base of the skull); SND (angle SND) - formed by lines $\underline{\mathrm{S}-\mathrm{N}}$ and $\underline{\mathrm{N}}$ $\underline{D}$ (indicates the anterior-posterior location of the symphysis (므 - the center of the symphysis ossification) of the lower jaw to the base of the skull); WITS (indicator Wits) - distance between constructive points $\underline{\mathrm{AOClP}}$ and $\mathrm{BOcIP}$ - projections of the corresponding points $\underline{A}$ and $\underline{B}$ on the line apOcP. 
ppOcP (OcPSt, closing plane by Steiner), indicates a linear interjaw ratio in the anterior-posterior direction (if the projection of point $\underline{A}$ lies ahead of the projection of point $\underline{B}$ then the indicator takes a positive value; if the projection of point $\underline{A}$ lies behind the projection of point $\underline{B}$ then the indicator takes a negative value).

\section{Discussion}

To evaluate the position of the frontal group of teeth, several methods can be used by orthodontists. The most ancient method is to measure the inclination of the crown part on the gypsum diagnostic models with the help of a protractor (tooth inclination protractor) TIP [17] - rather cheap and simple method whose significance is significantly different from the teleroentgenographic data and allows only to assess the position of the vestibular-oral and mesiodistal inclinations relative to the occlusion plane, the definition of which is often complicated especially in persons with pronounced closure curves. The most promising and informative method is to use a dental computed tomography, which allows three-dimensional reproductions of bone tissues to be obtained and it is enough to accurately measure linear and angular parameters [2, 13]. Despite the gradual decrease in the price of equipment, an increase in the size of the matrix and an increase in the detail of the image, the method is not yet included in the protocol of orthodontic patient research. It should also be noted that at present, normative bases concerning three-dimensional characteristics of the tooth-jaw system are not presented.

The most accessible and used method is teleroentgenographic research that allows you to determine the position of the central axis of central incisors in relation to different anatomical structures. Different researchers have proposed different methods of determination, each of which has its drawbacks and advantages. So Stainer S. [43] used the angle S-N-A and determined the angular positions of the central axis of the upper central incisor to the lines of this angle, as well as the distance of the vestibular surface of the latter to the line N-A. Downs W. [14] used a inter-incisor angle and a line connecting the upper and lower jaws A-Pog to determine the position of the upper central incisors. Mc Namara [28] determined the distance of the vestibular surface of the central incisor to the perpendicular in relation to the Frankfurt horizontal, conducted through the point $A$. G. Schmuth [40] used the angle value to the palatal plane ANS-PNS and the angle and distance to the line N-A.

The mathematical analysis of the metric characteristics of the craniofacial complex allows us to create a valuable diagnostic tool for modeling the individual tooth-jaw norm of the patient, identifying the actual pathological abnormalities and methods of treatment [20,33]. Mathematically analyzed data of cephalometric studies allow to study evolutionary changes, genetic interconnection of ethnic groups, and to establish the influence of different morphological structures on the formation of craniofacial structures [1, 22]. Many studies point to the presence of various dependencies found by regression and correlation analyzes between different anatomical head structures and tooth-jaw system parameters [3, 34, 35, 39].

For Ukrainian young men and women with orthognathic bite we developed reliable regression models of individual teleroentgenographic characteristics of the position of upper central incisors with a determination coefficient greater than 0.50 , depending on the peculiarities of the metric characteristics of the craniofacial complex. It was established that in young men from 6 possible models, 5 were constructed with determination coefficient $R^{2}$ from 0.672 to 0.928 , and in young women - all 6 possible models with determination coefficient $R^{2}$ from 0.508 to 0.663 .

In the analysis of models with a determination coefficient higher than 0.50 , it was found that in young men most often the regression equations include - the angle AB_NPOG (12.0\%); distance COND_GN, inclination angle I, MAX maxillary length, Se_N distance, Nap angle, NBa-PtGn angle, SND angle and Wits indicator (by $8.0 \%$ ). In young women, most often the regression equations include - the angle AB_NPOG and the Wits indicator (by 15.4\%); angle N_POG (11.5\%); angle GI'SnPog' and the distance LPALAT (by $7.7 \%$ ).

In the previous study [12], in the simulation of individual teleroentgenographic characteristics of position of the lower central incisors in young women with orthognathic bite of 7 possible regression models was constructed with 5 with a determination coefficient from 0.694 to 0.849 , the most frequent (from 7.7 to $11.5 \%$ ) included were the angle ANB, facial vertical index, lower face height ANS_ME, NBA_PTGN face angle and distance S_E. In young women, all 7 possible models with a determination coefficient from 0.595 to 0.794 (which is also lower than in the models of the position of the upper central incisors) were constructed, which most often (from 5.6 to $16.7 \%$ ) included the angle N_POG, the Wits indicator, the inclinational angle $\mathrm{I}$, and the $\mathrm{H}$ angle, the angle of the MM and the angle of NBa-PtGn (by $5.6 \%$ )

The models we have developed will allow orthodontists to more correctly and effectively change the position of the frontal group of teeth and achieve in the treatment maximum physiological and aesthetic results.

\section{Conclusions}

In young men of 6 possible models idividual teleroentgenographic characteristics of the position of upper central incisors, have been constructed 5 with coefficients of determination from 0.672 to 0.928 , and for young women - all 6 possible models with determination coefficient from 0.508 to 0.663 . In young men most often the regression equations include - the angle $A B \_N P O G$ $(12.0 \%)$; distance COND_GN, inclination angle I, MAX maxillary length, Se_N distance, NaPog angle, NBa-PtGn angle, SND angle and Wits indicator (by $8.0 \%$ ); and in young women - the angle AB_NPOG and the Wits indicator (by $15.4 \%)$; angle N_POG $(11.5 \%)$; the angle Gl'SnPog' and the distance LPALAT (by $7.7 \%$ ). 


\section{References}

[1] Akgul, A. A., \& Toygar, T. U. (2002). Natural craniofacial changes in the third dec-ade of life: a longitudinal study. Am. J. Orthod. Dentofacial Orthop., 122(5), 512-522. doi: 10.1067/ mod.2002.128861

[2] Berco, M., Rigali, P. H., Miner, R. M., DeLuca, S., Anderson, N. K., \& Will, L. A. (2009). Accuracy and reliability of linear cephalometric measurements from cone-beam computed tomography scans of a dry human skull. Am. J. Orthod. Dentofacial Orthop., 136(1), 17-18. doi: 10.1016/ j.ajodo.2008.08.021

[3] Bingmer, M., Ozcan, V., Jo, J. M., Lee, K. J., Baik, H. S., \& Sneider, G. (2010). A new concept for the cephalometric evaluation of craniofacial pattern (multiharmony). Eur. J. Orthod., 32(6), 645-654. doi: 10.1093/ejo/cjp152

[4] Bowman, S. J., \& Johnston, L. E. Jr. (2000). The esthetic impact of extraction and nonextraction treatments on Caucasian patients. Angle Orthod., 70(1), 3-10. doi: 10.1043/00033219(2000)070<0003:TEIOEA>2.0.CO;2

[5] Bronfman, C. N., Janson, G., Pinzan, A., \& Rocha, T. L. (2015). Cephalometric norms and esthetic profile preference for the Japanese: a systematic review. Dental Press Journal of Orthodontics, 20(6), 43-51. doi: 10.1590/2177-6709.20.6.043051.oar

[6] Dallel, I., Khemiri, M., Fathallah, S., Ben Rejeb, S., Tobji, S., \& Ben Amor, A. (2015). Incisor repositioning: a new approach in orthodontics. Orthod. Fr., 86(4), 327-338. doi: 10.1051/ orthodfr/2015031

[7] de Oliveira, M. D. V., da Silveira, B. L., Mattos, C. T., \& Marquezan, M. (2015). Facial profile esthetic preferences: perception in two Brazilian states. Dental Press J. Orthod., 20(3), 88-95. doi: 10.1590/2176-9451.20.3.088-095.oar

[8] Dmitriev, M. O. (2016). Definition of normative cephalometric parameters by Steiner method for Ukrainian young men and women. World of Medicine and Biology, 3(57), 28-32.

[9] Dmitriev, M. O. (2017). Identification of normative cephalometric parameters based on $\mathrm{G}$. Schmuth method for young male and female Ukrainians. Reports of Morphology, 23(2), 288-292.

[10] Dmitriev, M. O. (2018). Determination of standard cephalometric parameters using the Downs method for Ukrainian adolescents. Reports of Morphology, 24(2), 22-26. doi: 10.31393/morphology-journal-2018-24(2)-03

[11] Dmitriev, M. O., Chugu, T. V., Gerasymchuk, V. V., \& Cherkasova, O. V. (2017). Determination of craniometric and gnatometric indicators by A. M. Schvartz metod for Ukrainian boys and girls. Biomedical and Biosocial Anthropology, 29, 53-58.

[12] Dmitriev, M. O., Gunas, I. V., Dzevulska, I. V., \& Glushak, A. A. (2018). Determination of individual cephalometric characteristics of the lower central incisors position in Ukrainian young men and women with orthognathic bite. Reports of Morphology, 24(3), 19-25. doi: 10.31393/ morphology-journal-2018-24(3)-03

[13] Dmitriev, N. A., Marchenko, A. V., Filimonov, V. Yu., \& Yasko, V. V. (2015). The study of the correctness of the metric studies of three-dimensional anatomical bone objects obtained using a cone-beam computer tomograph Morita Veraviewepocs 3D. Reports of Morphology, 21(2), 374-379.

[14] Downs, W. B. (1956). Analysis of the dentofacial profile. Angle Orthodontist, 26, 191-212.

[15] Erdinc, A. E., Nanda, R. S., \& Dandajena, T. C. (2007). Profile changes of patients treated with and without premolar extractions. Am. J. Orthod. Dentofacial Orthop., 132(3), 324-
331. doi: 10.1016/j.ajodo.2005.08.045

[16] Garcia, P. P., da Costa, R. G., Calgaro, M., Ritter, A. V., Correr, G. M., da Cunha, L. F., \& Gonzaga, C. C. (2018). Digital smile design and mock-up technique for esthetic treatment planning with porcelain laminate veneers. J. Conserv. Dent., 21(4), 455-458. doi: 10.4103/JCD.JCD_172_18

[17] Ghahferokhi, A. E., Elias, L., Jonsson, S., Rolfe, B., \& Richmond, S. (2002). Critical assessment of a device to measure incisor crown inclination. American Journal of Orthodontics and Dentofacial Orthopedics, 121(2), 185-191. PMID: 11840133

[18] Gunas, I. V., Dmitriev, M. O., Tikholaz, V. O., ShinkarukDykovytska, M. M., Pastukhova, V. A., Melnik, M. P., \& Rudiy, Yu. I. (2018). Determination of normal cephalometric parameters by J. McNamara method for Ukrainian boys and girls. World of Medicine and Biology, 1(63), 19-22. doi: 10.26724/2079-8334-2018-1-63-19-22

[19] Gunas, I. V., Dmitriev, M. O., Prokopenko, S. V., ShinkarukDykovytska, M. M., \& Yeroshenko, G. A. (2017). Determination regulatory cephalometric options by the method of Tweed International Foundation for Ukrainian boys and girls. World of Medicine and Biology, 4(62), 27-31. doi: 10.26724/2079-83342017-4-62-27-31

[20] Hammond, P., Hutton, T., Maheswaran, S., \& Modgil, S. (2003). Computational models of oral and craniofacial development, growth, and repair. Adv. Dent. Res., 17, 61-64. doi: 10.1177/ 154407370301700114

[21] Holdaway, R. A. (1984). A soft-tissue cephalometric analysis and its use in orthodontic treatment planning. Part II. Am. J. Orthod., 85, 279-293. doi: https://doi.org/10.1016/00029416(84)90185-4

[22] Kjellberg, H., Beiring, M., \& Albertsson Wikland, K. (2000). Craniofacial morphology, dental occlusion, tooth eruption, and dental maturity in boys of short stature with or without growth hormone deficiency. Eur. J. Oral. Sci., 108(5), 359-367. PMID: 11037751

[23] Kocadereli, I. (2002). Changes in soft tissue profile after orthodontic treatment with and without extractions. Am. J. Orthod. Dentofacial. Orthod., 122(1), 67-72. PMID: 12142899

[24] Kumari, L., \& Das, A. (2017). Determination of Tweed's cephalometric norms in Bengali population. Eur. J. Dent., 11(3), 305-310. doi: 10.4103/ejd.ejd 27416

[25] Lin, W. S., Zandinejad, A., Metz, M. J., Harris, B. T., \& Morton, D. (2015). Predictable restorative work flow for computeraided design/computer-aided manufacture-fabricated ceramic veneers utilizing a virtual smile design principle. Oper. Dent., 40(4), 357-363. doi: 10.2341/13-295-S

[26] Linjawi, A. I. (2016). Age- and gender-related incisor changes in different vertical craniofacial relationships. J. Orthod. Sci., 5(4), 132-137. doi: 10.4103/2278-0203.192116

[27] Lombardo, L., Perri, A., Arreghini, A., Latini, M., \& Siciliani, G. (2015). Three-dimensional assessment of teeth first-, secondand third-order position in Caucasian and African subjects with ideal occlusion. Prog. Orthod., 16, 1-11. doi: 10.1186/ s40510-015-0086-9

[28] McNamara, J. A. Jr. (1984). A method of cephalometric evaluation. Am. J. Orthod., 86(6), 449-469. PMID: 6594933

[29] Meereis, C. T., de Souza, G. B., Albino, L. G., Ogliari, F. A., Piva, E., \& Lima, G. S. (2016). Digital smile design for computerassisted esthetic rehabilitation: Two-year follow-up. Oper. Dent., 41(1), 13-22. doi: 10.2341/14-350-S

[30] Meneghini, F., \& Biondi, P. (2012). Clinical facial analysis. 
Elements, principles, and techniques (2nd ed.). Berlin: Springer-Verlag Berlin Heidelberg.

[31] Miranda, M. E., Olivieri, K. A., Rigolin, F. J., \& de Vasconcellos, A. A. (2016). Esthetic challenges in rehabilitating the anterior maxilla: A Case report. Oper. Dent., 41(1), 2-7. doi: 10.2341/ 14-269-S

[32] Mohammed, S. A., Nissan, L. M. K., Ahmed, H. M. A., \& Nahidh, M. (2018). Sagittal Lips' Positions in Different Facial Types. J. Res. Med. Dent. Sci., 6(1), 16-21. doi: 10.24896/ jrmds.2018614

[33] Nakasima, A., Terajima, M., Mori, N., Hoshino, Y., Tokumori, K., Aoki, Y., \& Hashimoto, S. (2005). Three-dimensional computergenerated head model reconstructed from cephalograms, facial photographs, and dental cast models. Am. J. Orthod. Dentofacial. Orthop., 127(3), 282-292. doi: 10.1016/ j.ajodo.2003.11.030

[34] Perinetti, G., Ceschi, M., Scalia, A., \& Contardo, L. (2018). Cephalometric Floating Norms for the B Angle and MMBPWits. BioMed Research International, 2018, Article ID 8740731, 6. doi: https://doi.org/10.1155/2018/8740731

[35] Perinetti, G., Cordella, C., Pellegrini, F., \& Esposito, P. (2008). The prevalence of malocclusal traits and their correlations in mixed dentition children: results from the Italian OHSAR Survey. Oral Health \& Preventive Dentistry, 6(2), 119-129. PMID: 18637389

[36] Profit, R. W., Fields, H. W., \& Sarver, D. M. (trans. from the English; Ed. L.S. Persina) (2006). Modern Orthodontics. M.: MEDpress-inform. ISBN 978-5-00030-448-8

[37] Rathod, A. B., Araujo, E., Vaden, J. L., Behrents, R. G., \& Oliver, D. R. (2015). Extraction vs no treatment: Long-term facial profile changes. Am. J. Orthod. Dentofacial Orthop., 147(5), 596-603. doi: 10.1016/j.ajodo.2015.01.018.

[38] Reshad, M., Cascione, D., \& Magne, P. (2008). Diagnostic mock-ups as an objective tool for predictable outcomes with porcelain laminate veneers in esthetically demanding patients: A clinical report. J. Prosthet. Dent., 99(5), 333-339. doi: 10.1016/S0022-3913(08)00056-5

[39] Scala, A., Auconi, P., Scazzocchio, M., Caldarelli, G., McNamara, J. A., \& Franchi, L. (2014). Complex networks for data-driven medicine: the case of Class III dentoskeletal disharmony. New Journal of Physics., 16(11), 1-17. doi: 10.1088/1367-2630/ 16/11/115017

[40] Schmuth, G. P. F. (1971). Methodische Schwierigkeiten bei der Anwendung der Röntgenkephalometrie in der Kieferorthopädie. Fortschritte der Kieferorthopädie, 32(2), 317-325.

[41] Schwarz, A. M. (1960). Röntgenostatics; practical evaluation of the tele-X-ray-photo. Publisher: Brooklyn, N.Y.: Leo L. Bruder.

[42] Shindoi, J. M., Matsumoto, Y., Sato, Y., Ono, T., \& Harada, K. (2013). Soft tissue cephalometric norms for orthognathic and cosmetic surgery. J. Oral. Maxillofac. Surg., 71(1), 24-30. doi: 10.1016/j.joms.2012.08.015

[43] Steiner, C. C. (1959). Cephalometrics in clinical practice. Angle Orthod., 29, 8-29.

[44] Tweed, C. H. (1954). The Frankfort-Mandibular Incisor Angle (FMIA) in Orthodontic Diagnosis, Treatment Planning and Prognosis. Angle Orthod., 3, 121-169.

[45] Wholley, C. J., \& Woods, M. G. (2003). The effects of commonly prescribed premolar extraction sequences on the curvature of the upper and lower lips. Angle Orthod., 73(4), 386-395. doi: 10.1043/0003-3219(2003)073<0386:TEOCPP>2.0.CO;2

[46] Zierhut, E. C., Joondeph, D. R., Artun, J., \& Little, R. M. (2000). Long term profile changes associated with successfully treated extraction and nonextraction Class II, Division I malocclusions. Angle Orthod., 70(3), 208-219. doi: 10.1043/ 0003-3219(2000)070<0208:LTPCAW>2.0.CO;2

\section{ВИЗНАЧЕННЯ ІНДИВІДУАЛЬНИХ ЛІНІЙНИХ ТА КУТОВИХ ХАРАКТЕРИСТИК ПОЛОЖЕННЯ ВЕРХНІХ ПРИСЕРЕДНІХ РІЗЦІВ В УКРАЇНСЬКИХ ЮНАКІВ I ДІВЧАТ 3 ОРТОГНАТИЧНИМ ПРИКУСОМ \\ Дмітрісв М.О., Гунас І.В., Гненна В.О., Смолко Н.М.}

Враховуючи важливість визначення телерентгенографічних показників просторового положення присередніх різців виникає наукова та клінічна зацікавленість у проведенні подібних досліджень. Мета дослідження - шляхом вивчення цефалометричних показників і проведення прямого покрокового регресійного аналізу розробити у юнаків та дівчат України з ортогнатичним прикусом математичні моделі індивідуальних характеристик положення верхніх присередніх різців. За допомогою пристрою Veraviewepocs 3D, Моріта (Япония) у 38 юнаків (віком від 17 до 21 року) та 55 дівчат (віком від 16 до 20 років) з оклюзією, наближеною до ортогнатичного прикусу, та збалансованими обличчями були отримані бокові телерентгенограми.

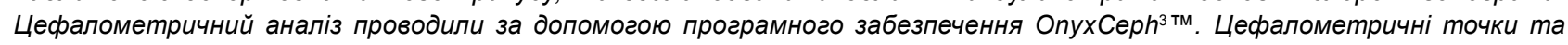
вимірювання проводили заідно рекомендацій A.M. Schwarz, J. McNamara, W.B. Downs, R.A. Holdway, P.F. Schmuth, C.C. Steiner ma C.H. Tweed. У ліцензійному статистичному пакеті "Statistica 6.0" з використанням прямого покрокового регресійного аналізу проведено моделювання наступних телерентгенографічних характеристик положення верхніх присередніх різців: відстані 1u_APog, відстані 1u_Avert, відстані 1u_NA, кута Max1_NA, кута Max1_SN і кута Max1_SpP. B юнаків і дівчат із оклюзією, наближеною до ортогнатичного прикусу, та збалансованим обличчям розроблені достовірні регресійні моделі індивідуальних телерентгенографічних характеристик положення верхніх присередніх різців з коефіцієнтом детермінації більиим 0,50 в залежності від особливостей метричних характеристик краніофраціального комплексу: в юнаків із 6 можливих моделей побудовано 5 з коефіцієнтом детермінації $R^{2}$ від 0,672 до 0,928, а у дівчат - усі 6 можливих моделей з коефіцієнтом детермінації R2 від 0,508 до 0,663. При аналізі моделей з коефіцієнтом детермінації більшим 0,50 встановлено, що в юнаків найбільш часто до регресійних рівнянь входять - кут AB_NPOG (12,0\%); відстань COND_GN, інклінаційний кут I, довжина верхньої щелепи MAX, відстань Se_N, куm NaPog, куm NBa-PtGn, куm SND та показник Wits (по 8,0\%). У дівчат найбільш часто до моделей входять - куm AB_NPOG і показник Wits (по 15,4\%); куm N_POG (11,5\%); куm GI'SnPog' і відстань LPALAT (по 7,7\%).

Ключові слова: положення верхніх присередніх різців, цефралометрія, регресійний аналіз, юнаки та дівчата, ортогнатичний прикус.

\section{ОПРЕДЕЛЕНИЕ ИНДИВИДУАЛЬНЫХ ЛИНЕЙНЫХ И УГЛОВЫХ ХАРАКТЕРИСТИК ПОЛОЖЕНИЯ ВЕРХНИХ ЦЕНТРАЛЬНЫХ РЕЗЦОВ У УКРАИНСКИХ ЮНОШЕЙ И ДЕВУШЕК С ОРТОГНАТИЧЕСКИМ ПРИКУСОМ \\ Дмитриев Н.А., Гунас И.В., Гненная В.О., Смолко Н.Н.}

Учитывая важность определения телерентгенографических показателей пространственного положения медиальных резцов возникает научная и клиническая заинтересованность в проведении подобных исследований. Цель исследования - 
путем изучения цефалометрических показателей и проведения прямого пошагового регрессионного анализа разработать у юношей и девушек Украины с ортогнатическим прикусом математические модели индивидуальных характеристик положения верхних медиальных резцов. С помощью устройства Veraviewepocs 3D, Mорита (Япония) у 38 юношей (в возрасте от 17 до 21 года) и 55 девочек (в возрасте от 16 до 20 лет) с окклюзией, приближенной к ортогнатическому прикусу, и сбалансированными лицами были получены боковые телерентгенограммы. Цефралометрический анализ проводили с помощью

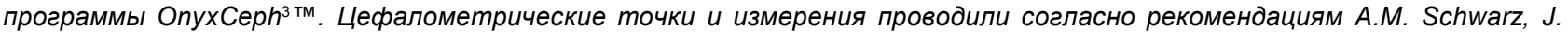
McNamara, W.B. Downs, R.A. Holdway, P.F. Schmuth, C.C. Steiner и C.H. Tweed. В лицензионном статистическом пакете "Statistica 6.0" с использованием прямого пошагового регрессионного анализа проведено моделирование следующих телерентгенографических характеристик положения верхних медиальных резцов: расстояния 1u_APog, расстояния 1u_Avert, расстояния 1u_NA, угла Max1_NA, угла Max1_SN и угла Max1_SpP. У юношей и девушек с окклюзией, приближенной к ортогнатическому прикусу, и сбалансированным лицом разработаны достоверные регрессионные модели индивидуальных телерентгенографических характеристик положения верхних медиальных резцов с коэфрфициентом детерминации большим, чем 0,50 в зависимости от особенностей метрических характеристик краниофациального комплекса: у юношей из 6 возможных моделей построено 5 с коэфрфициентом детерминации $R^{2}$ от 0,672 до 0,928, а у девушек - все 6 возможных моделей с коэффрициентом детерминации $R^{2}$ om 0,508 до 0,663. При анализе моделей с коэффрициентом детерминации большим 0,50 установлено, что у юношей наиболее часто к регрессионным уравнениям входят - угол $A B \_N P O G$ (12,0\%); расстояние COND_GN, инклинационный угол I, длина верхней челюсти MAX, расстояние Se_N, угол NaPog, угол NBa-PtGn, угол SND и показатель Wits (по 8,0\%). У девушек наиболее часто к моделям входят - угол AB_NPOG и показатель Wits (по 15,4\%); угол N_POG (11,5\%); угол GI'SnPog "и расстояние LPALAT (по 7,7\%).

Ключевые слова: положение верхних центральных резцов, цефалометрия, регрессионный анализ, юноши и девушки, ортогнатический прикус. 